\title{
VANHUSTYÖN KEHITTÄMISHANKKEET VANHUSPALVELUJÄRJESTELMÄN VASTUITA RAKENTAMASSA
}

\author{
Päivi Ahosola: TtM, FT, Tampereen yliopisto \\ Kirsi Lumme-Sandt: FT, dosentti, Tampereen yliopisto
}

paiviahos@gmail.com, kirsi.lumme-sandt@tuni.fi

Janus vol. 27 (3) 2019, 228-245

\section{(J) J a II U S}

$\mathbf{y}$ VERTAISARVIOITU
KOLLGIALT GRANSKAD KOLLEGIALT GRAN
PEER-REVIEWED
Www. tsv.filtunnus

Tiivistelmä

Hankkeista ja projekteista on tullut keskeinen uudistamisen väline kuntien vanhuspalveluissa. Hankkeet kiinnittyvät usein kansallisiin sekä kuntien omiin vanhuspoliittisiin ohjelmiin ja strategioihin. Tämän artikkelin tavoitteena on tutkia mihin vanhustyön sisällöllisiin teemoihin vanhustyön kehittämishankkeita on 2000-luvulla suunnattu, miten valintoja perustellaan ja millaisia tuloksia on saavutettu erityisesti omaisettomien hoivan tarvitsijoiden hoivan ja palveluiden kehittämisessä. Tutkimuksen aineistona on kehittämishankekuvauksia $(n=237)$ ja muuta hankemateriaalia. Aineiston analyysin tueksi on laadittu hoivan yhteiskunnalliseen työnjakoon (epävirallinen, virallinen, palkallinen, palkaton) perustuva analyysikehikko. Menetelmänä on käytetty sisällön analyysiä. Tutkimuksen tuloksena on, että vanhustyön ja -palveluiden kehittämishankkeissa painottuvat omaisiin ja muuhun epäviralliseen hoivaan liittyvät hankkeet.Viralliseen hoivaan ei sen sijaan juurikaan kohdistettu kehittämishankkeita eikä omaisettomia vanhuksia mainittu. Syrjäytymistä vastustavat hankkeet puolestaan edellyttivät syrjäytyneen toimija-aseman omaksumista.

\section{JOHDANTO}

Ikääntyneille suunnattuja hoivapalveluita kehitetään enenevässä määrin erilaisten hankkeiden ja projektien kautta.Tässä artikkelissa tutkitaan Uudenmaan maakunnan osalta, mihin suuntaan suomalaista vanhuspalvelujärjestelmää on pyritty kehittämään 2000-luvun vanhustyön hankkeissa sekä miten julkisen ja yksityisen vastuita näissä hankkeissa rakennetaan. Lähestymme tutkimuskohdetta erityisesti virallisen, julkisen, hoivan avulla selviytyvien vanhojen ihmisten näkökulmasta, ja olemme kiinnostuneita siitä, miten heidän palveluitaan ja hoivaansa on pyritty kehittämään. Hoivalla tarkoitamme laajasti kaikkia niitä toimia, joihin ihmiset tarvitsevat toisen ihmisen apua arjesta selviytyäkseen.
Julkisten hyvinvointipalveluiden uudistaminen voidaan nähdä tärkeänä palveluiden ajantasaisuuden ja legitimiteetin kannalta väestön, yhteiskunnan ja tietämyksen muuttuessa. Jo pitkään hallitusohjelman ja hoivapolitiikan mukaiset linjaukset ovat merkinneet vahvaa painotusta kotona asumiseen ja omaishoivan kehittämiseen. Projektitoiminnalla, jonka lähtökohtaisena oletuksena on aina jonkinlainen muutoksen tavoittelu, hyvinvointivaltiollista vakiintunutta toimintaa on pyritty muokkaamaan monimuotoisemmaksi (Rinne 2009, 23). Kun vanhusväestöön ja -työhön kohdistuvia projekteja on pyritty suuntaamaan valtakunnallisista strategioista käsin, keskeisenä perusteluna muutoksen tarpeelle on ollut väestön ikääntyminen (Paasivaara ym. 2013, 12). Van- 
husväestön kasvulla on myös perusteltu julkisen avun rajaamisen tarvetta. Kun julkista hoivaa on rajattu, samalla perheiden vastuuta ja hoivan yhteiskunnallista työjakoa on määritelty uudelleen.

2000-luvulla lähes kaikki suomalaiset sosiaali- ja terveydenhuollon keskeisimmät uudistukset on toteutettu osana kansallisia ohjelmia. Uudistamisen käytännön välineenä toimivien hankkeiden ja projektien määrä kuntien hyvinvointipalveluissa on kasvanut varsin suureksi. Projektitoiminta on saanut kunnissa niin vahvan jalansijan, että sen varaan on rakennettu kokonaisia organisaatioita, jolloin hankkeille pohjautuva toiminta on saanut institutionaalisia piirteitä (Rinne 2009, 16, 17). Projekti uuden julkisjohtamisen mukaisena hallinnon organisaationa on tuonut hyvinvointipalveluihin sopimukset, arvioinnit, ohjelmat ja kumppanuudet (Sulkunen 2006, 17). Kehittämishankkeet voidaan siis hyvällä syyllä olettaa keskeisiksi välineiksi julkisen vastuun rajaamisessa sekä perheiden ja muiden informaalien toimijoiden esiin nostamisessa.

Perheiden vastuun lisäämistä hoivatyössä ja sen koordinoinnissa on kutsuttu hoivan informalisoinniksi (Rostgaard \& Szebehely 2012) sekä uusfamilismiksi (Julkunen 2006, 110). Kääntöpuolena tälle muutokselle on ollut julkisen avun varassa elävien vanhojen ihmisten haavoittuvuuden kasvu. Joidenkin tutkimusten mukaan (ks. Dahlberg \& McKee 2016) ne, jotka ovat vailla omaista tai muuta hoidon varmistajaa, ovat saaneet jopa vähemmän myös formaalia hoivaa kuin ne, joilla on omaisia. Riittämättömästi apua saaneet ovat usein yksinasuvia ja pienituloisia (Van Aerschot 2014). Toinen kehityskulku on markkinoistaminen, mikä sekin on kohdistunut vahvasti juuri niihin palveluihin, joissa asiakkaiden haavoittuvuus on suurinta (Anttonen ym. 2013, 294).

Tämän artikkelin lähtökohtana on ajatus siitä, että erilaisilla kehittämishankkeilla on merkittävä tehtävä vanhustyön suunnan muokkaajana kunnissa. Juuri kehittämishankkeilla paitsi kehitetään myös rajataan palveluita ja pyritään hallitsemaan ja ohjaamaan palveluiden käyttäjiä toivottuun suuntaan (vrt. Miller \& Rose 2010). Politiikkalinjaukset toistuvat kielellisinä valintoina kehittämishankkeissa ja ennen pitkää myös käytännön vanhustyössä. Muutos tapahtuu pitkälti kielen käytön kautta, kun kehittämistoimien suuntaaminen strategisesti valittuihin aiheisiin muokkaa kielenkäyttöä (ks. myös Filander 2000).

Kun kehittämishankkeet ja -projektit tuodaan vanhustyön käytännön toimintakentille, ne tulevat lähelle käytännön vanhustyön tekijöitä - sekä ammatillisia että ei-ammatillisia toimijoita. Sen lisäksi, että kehittämishankkeiden linjaukset ja toimenpiteet konkreettisesti muovaavat palvelujärjestelmää ja sen kieltä, hankkeiden ympärille rakentuva sosiaalinen järjestelmä tarjoaa tietynlaisia asemia eri toimijoille ja muokkaa vanhustyön sosiaalisia käytäntöjä erityisesti kielen ja siinä tuotettujen merkitysten ja valtasuhteiden kautta (Smith 2005).

Tämän tutkimuksen yleisenä tavoitteena on lisätä ymmärrystä siitä, millainen rooli kehittämishankkeilla on 
ollut familistisen käänteen jalkauttajana vanhustyössä. Juha Sipilän hallituksen strategisen ohjelman linjauksissa kehittämishankkeiden erityisenä kiinnostuksen kohteena on ollut kotihoidon ja omaishoidon vahvistaminen (Suomen hallituksen strateginen ohjelma 2015). Siten kysymys julkisen ja yksityisen vastuun ja toiminta-alueiden määrittelystä on erityisen ajankohtainen.

Yksityiskohtaisina tavoitteina on analysoida sitä, (1) mihin vanhuspalveluiden ja -työn sisällöllisiin teemoihin (vanhustyön) kehittämishankkeita on suunnattu. Tämän jälkeen selvitetään, (2) miten hankkeet perustelevat kohdistumistaan (a) informaaliin tai (b) formaaliin hoivaan tai (c) omaisettomia, formaalin hoivan varassa olevia vanhuksia koskeviin kysymyksiin. Lopuksi tarkastellaan, (3) mitä hankkeilla on saavutettu erityisesti formaalin hoivan avulla selviytyvien vanhojen ihmisten hoivan ja palveluiden kehittämisessä.

Läpi analyysin kiinnitetään erityistä huomiota siihen, millaisena hankeraporteissa tuotetaan julkisen vallan ja toisaalta perheiden vastuuta sekä millaista osallisuutta ja toimijuutta teksteissä tuotetaan julkisen avun varassa eläville, esimerkiksi perheettömille, vanhoille ihmisille.

\section{INSTITUTIONAALINEN KONTEKSTI \\ - KEHITTÄMISTOIMINTA OSANA VANHUSTYÖN HALLINTAA}

Suomalaisen hyvinvointivaltion 1990-luvulta alkanutta murrosta ja uusien johtamisoppien rantautumista julkishallintoon on kuvattu siirtymisenä projektiyhteiskuntaan (Rinne
2009) ja projekti- ja kehittämisvaltioon (Julkunen 2006, 264). Valtionhallinnossa projektitoiminta oli yhteydessä suunnittelukulttuurin vahvistumiseen jo 1960- ja 70-luvuilla. 1980-luvulla jatkunut suuntaus vahvisti projektiluontoisen kehittämistyön merkitystä edelleen. Edelleen vauhtia projektitoiminnalle antoivat 1980-luvulla toimeenpantu sosiaalialaa ohjaava lainsäädäntö, Sosiaali- ja terveysalan tutkimus- ja kehittämiskeskuksen Stakesin perustaminen vuonna 1992 sekä Suomen liittyminen Euroopan Unionin jäseneksi vuonna 1995. (Rinne $2009,16,17$.$) Ohjausjärjestelmässä$ muutokset merkitsivät valtakunnallisen ohjauksen muutosta normiohjauksesta informaatio- ja hankeohjauksen suuntaan (Aaltonen ym. 2009) sekä suunnittelu- ja päätösvastuun hajauttamista paikalliselle tasolle. (ks. myös Sulkunen 2006, 26-28.)

Valtion hankerahoitusta on kanavoitu kuntiin laajojen kehittämishankkeiden kautta. Hanke- tai ohjelmaohjaus voidaan ymmärtää osana vanhuspolitiikan valtakunnallista ohjausta, jonka merkitys korostui 2000-luvulle tultaessa. Kehittämishankkeita ohjaamalla ja rahoittamalla valtio ohjaa kuntien vanhustyön kehittämistä valtakunnallisesti haluttuihin suuntiin. Hankeohjausta voidaan edellä mainitun perusteella pitää sekä informaatio- että resurssiohjauksena (Aaltonen ym. 2009). Leena Kaljunen $(2011,50)$ esittää ohjelmaohjauksen erillisenä kuntien palvelutoiminnan ohjausmuotona, jossa valtion tavoitteena on kunnallisten kehittämishankkeiden aikaansaaminen ja kuntien tavoitteena puolestaan kehittämishankkeisiin suunnatun rahan hyödyntäminen omassa palvelutuotannossaan. Ke- 
hittämishankkeisiin saatava rahoitus on kunnille merkittävä rahoituslähde valtionosuuksien, verotulojen ja palveluiden myyntitulojen rinnalla (mt., 39).

Rahoitusta on alueellistettu myös lääninhallitusten ja myöhemmin ELYkeskusten hoidettavaksi. Kuntien kehittämistyön tueksi perustettiin vuonna 2002 yhdeksän pysyvää alueellista sosiaalialan osaamiskeskusta, kun toimintaa säätelevä laki (1230/2001) tuli voimaan. Esimerkiksi Etelä-Suomen osaamiskeskus, ESO, on verkosto-organisaatio, joka muodostui kolmesta yksiköstä. Valtion lisäksi kuntien kehittämistyötä ovat rahoittaneet useat muut tahot, kuten Euroopan unioni ja erityisesti Raha-automaattiyhdistys (RAY).

Suurista valtakunnallisista hankkeista sosiaalialan kehittämishankkeen yhtenä painopistealueena oli vanhusten palvelujen saatavuuden ja laadun parantaminen. Vanhustenhuollon kehittämiseen jaettiin hankkeessa yhteensä 17,4 miljoonaa euroa vuosina 2004 -2007. (STM 2008, 80.) Vuodesta 2008 lähtien Kaste-ohjelma oli sosiaali- ja terveysministeriön (STM) pääohjelma. Sitä toteutettiin kahtena ohjelmana vuosina 2008-2011 sekä 2012-2016. Kasteohjelman tavoitteita olivat mm. hyvinvointi- ja terveyserojen kaventaminen sekä asiakaslähtöisyyden lisääminen (STM 2016). Uusin hallitusohjelmaan liittyvä STM:n hankekokonaisuus on nimeltään "Kehitetään ikäihmisten kotihoitoa ja kaikenikäisten omaishoitoa". Siihen liittyviin hankkeisiin on myönnetty 14,2 miljoonaa euroa (http:// stm.fi/hankkeet/koti-ja-omaishoito, katsottu 12.2.2018).
Raha-automaattiyhdistys on ollut merkittävä toiminnan rahoittaja hyvinvointipalveluiden kehittämisessä. Koska sen rahoitus on kohdennettu järjestöille, se on myös korostanut järjestöjen roolia kunnan palvelutoimintojen täydentäjänä (Kaljunen 2011, 39). Tämä puolestaan on aiheuttanut muutospaineita perinteisesti vapaaehtoisuuden eetokseen perustuvalle järjestötoiminnalle (Rinne 2009). Vaikka tuki on kohdennettu järjestöille, rahoitetuilla hankkeilla on pitänyt olla kunnan tuki silloin kun hankkeet liittyvät kunnan palvelujärjestelmään. Raha-automaattiyhdistyksen hallituksessa, joka on vastannut rahoituspäätösten tekemisestä, on ollut edustus ministeriöistä. Näin ollen RAY:n tukemat järjestöjen toteuttamat hankkeet asettuvat osaksi valtakunnallista kuntien myötäilemää hankeohjausta. RAY:n avustustoiminta siirtyi sosiaalija terveysministeriön yhteyteen perustettuun Sosiaali- ja terveysjärjestöjen avustuskeskukseen (STEA) vuoden 2017 alusta.

\section{Teoreettiset JA Metodologiset LÄHTÖKOHDAT}

Teoreettis-metodologisena lähtökohtana artikkelissa on hoivan yhteiskunnallisen työnjaon näkökulma. Hoiva on sukupuolitettu, poliittinen ja yhteiskunnallinen kysymys, jonka järjestämiseen ja tuottamiseen liittyvät ratkaisut muovaavat työnjaollisia suhteita ja taloudellisia järjestyksïa. Toisaalta juuri taloudelliset prioriteetit ovat vaikuttamassa hoivan työnjakoon formaalin ja informaalin välillä. Hoivapolitiikan historia voidaan hahmottaa jatkuvana kamppailuna, jossa vastuut siirtyvät formaalin/julkisen ja informaalin/yksityi- 
sen välillä. (Anttonen 2009, Hoppania ym. 2016.)

Analyysimenetelminä käytettiin ensiksi aineistolähtöistä sisällönanalyysia, jonka avulla muodostettiin teemarunko niistä sisällöllisistä teemoista, joihin hankkeet kohdistuivat. Aineisto koodattiin ko. teemojen mukaan. Analyysiä varten rakennettiin analyyttinen viitekehys (taulukko 1) hoivan yhteiskunnallisen työnjaon (julkisen ja yksityisen hoivavastuun, ks. esim. Sipilä 2003) pohjalta. Viitekehyksen ohjaamana osa teemoista voitiin luokitella joko informaaliin tai formaaliin hoivaan tai informaalin
Kehittämishankkeiden varsinainen analyysi kohdistui hoivaa koskevien merkitysten analyysiin. Analyyttisen viitekehyksen (taulukko 1) ohjaamana analyysi kohdistettiin erityisesti perheitä, perheettömyyttä sekä julkista ja yksityistä vastuuta koskevien merkitysten ja sitoumuksien avaamiseen. Sitoumuksia voidaan esittää tekstissä avoimesti tai niitä voidaan tuottaa implisiittisesti esittämällä ne lähtökohtina, joita ilman teksti ei avaudu lukijalle.

Analyysin taustalla on käsitys sekä kuntien kehittämishankkeiden valtakunnallisesta informaatio-, hanke- ja ohjelma-

Taulukko 1. Tutkimuksen analyysikehikko

\begin{tabular}{|l|l|l|l|l|}
\hline & \multicolumn{2}{|c|}{ PALKATON } & \multicolumn{2}{c|}{ PALKALLINEN } \\
\hline & Avun antaja & \multicolumn{1}{|c|}{ Avun ehtoja } & Avun antaja & \multicolumn{1}{|c|}{ Avun ehtoja } \\
\hline INFORMAALI HOIVA & $\begin{array}{l}\text { Perhe, } \\
\text { ystävä, } \\
\text { sukulainen, } \\
\text { naapuri, } \\
\text { henkilö itse }\end{array}$ & $\begin{array}{l}\text { On perhettä, } \\
\text { omaisia tai } \\
\text { läheisiä, } \\
\text { itsellä on } \\
\text { toimintakykyä }\end{array}$ & Omaishoitajat & $\begin{array}{l}\text { On omais- } \\
\text { hoitajaksi } \\
\text { ryhtyvä } \\
\text { läheinen }\end{array}$ \\
\hline FORMAALI HOIVA & $\begin{array}{l}\text { Vapaaehtois- } \\
\text { työntekijä, } \\
\text { virallisen kautta } \\
\text { välitetty } \\
\text { vertaisavun } \\
\text { antaja }\end{array}$ & $\begin{array}{l}\text { On saatavilla } \\
\text { vapaaehtoista } \\
\text { apua }\end{array}$ & $\begin{array}{l}\text { Ammatillinen } \\
\text { työntekijä }\end{array}$ & $\begin{array}{l}\text { Apua on } \\
\text { saatavilla, se } \\
\text { on riittävää ja } \\
\text { siihen on } \\
\text { varaa }\end{array}$ \\
\hline
\end{tabular}

hoivan puuttumiseen liittyviksi. Tämä ei ollut täysin ongelmatonta, koska empiirisesti tarkasteltuna informaalin ja formaalin rajat liukuvat (Kröger 2009, 122). Viitekehystä varten näiden välille oli kuitenkin tehtävä selkeä jako. Lisäksi analyysikehikko ja aineistosta laadittu havaintomatriisi mahdollistivat aineiston monipuolisen, myös määrällisen, tarkastelun. ohjauksesta että kehittämishankkeista itsessään paitsi ohjauksena myös hallinnan muotona ja välineenä. Hallinnan näkökulmasta toimijoita eivät ohjaa vain tietyt esimerkiksi valtiolliset tahot vaan hallinta toteutuu moninaisten toimijoiden kautta (Miller \& Rose 2010). Organisaation teksteillä nähdään olevan keskeinen merkitys hallinta-/valtasuhteiden (relations of ruling) määrittelijänä (Smith 2005, Satka \& Skehill 2011). 
TUTKIMUSAINEISTON HAKU JA ANALYYSIN ETENEMINEN

Artikkelin tutkimusaineistoksi tavoiteltiin kaikkia Uudenmaan kunnissa 2000-luvulla toteutettujen hankerahoitusta saaneiden vanhustyöhön kohdistuvien kehittämishankkeiden rahoitustietoja, hankekuvauksia ja -raportteja sekä www-sivustoja siltä osin kun ne olivat saatavissa. Tutkimalla rahoitettuja hankkeita, tutkitaan samalla vanhuspoliittista ohjausta. Aineistoa haettiin eri tietokannoista ja sivustoilta useampaan otteeseen. Kuntien omista hankkeista, jotka eivät saaneet ulkopuolista rahoitusta, ei haettu tietoa, eikä sitä olisi ollut helposti saatavissakaan. Aineiston muodostaa vuosina 2011, 2016 ja 2017 tehtyjen hakujen perusteella kerätty edellä kuvattu hankemateriaali.

Kehittämishankkeita etsittiin Kasteohjelmasta valtionavustusta saaneista hankkeista, joiden joukossa ei kuitenkaan ollut yhtään Uudellamaalla toteutettua vanhustyön hanketta. Sosiaalialan kehittämisyksiköiden kautta Uudellamaalla rahoitusta saaneet hankkeet käytiin läpi ja niiden joukosta löytyi useampia vanhustyön hankkeita. Analyysin ulkopuolelle jätettiin Soccan GeroMetro-hanke, jota kuvattiin pysyvänä kehittämisrakenteena hanketoiminnan asemasta.

ESR-hankkeet selattiin ESR-tietopalvelusta Tavoite 2 B -ohjelman ja Etelä-Suomen osalta mutta yhtään vanhustyöhön kohdistuvaa hanketta Uudellamaalla ei löytynyt. Uusimmassa sosiaali- ja terveysministeriön rahoittamassa hallituksen I \& O -kärkihankkeessa rahoitusta saaneiden joukosta löytyi Uudenmaan alueelta yksi hanke,
Täydentäen toimivaa (Täytyy), Porvoosta.

RAY:n avustustietokantaan (https:// www.ray.fi) tehtiin useampia hakuja. Jo vuonna 2011 oli haettu vanhustyöhön kohdistuvia hankkeita Uudenmaan alueella. Avustustietokannan hakukriteereitä oli kuitenkin vuosien varrella muutettu niin, että vuosina 2016 ja 2017 erityisesti vanhustyöhön kohdistuvia hankkeita ei ollut mahdollista hakea. Sen sijaan oli mahdollista hakea ikääntyvien järjestöille, omaisjärjestöille sekä hyvinvoinnin ja kuntoutuksen erityisjärjestöille kohdistuvia hankkeita. Näitä haettiin rajaten haku Uudenmaan kuntiin ja vuosiin 2000-2016 (avustuslajina projektiavustus). RAY:n rahoitusta saaneita hankkeita löytyi yhteensä 229. Hankkeet olivat kestäneet keskimäärin 3,5 vuotta ja saaneet rahoitusta keskimäärin 207450 euroa.

Hankkeiden sisällölliset aihealueet luokiteltiin hankekuvausten perusteella aineistolähtöisesti 34 teemaan (liitetaulukko 1).Yhdessä hankkeessa oli yleensä useita teemoja. Aineisto koodattiin tämän teemarungon mukaan, jonka jälkeen aineistosta muodostettiin havaintomatriisi.

Teemoja yhdisteltiin hoivan yhteiskunnallisen työnjaon näkökulmasta relevantteihin teemayhdistelmiin. Informaaliin ja palkattomaan hoivatyöhön viittaavat teemat yhdistettiin samoin kuin viralliseen, ammatilliseen, hoivatyöhön kohdistuvat teemat. Koska nimenomaisesti omaisettomia vanhuksia koskevia hankkeita ei ollut, kolmas teemayhdistelmä muodostettiin yksinäisyyteen tai syrjäytymiseen kiinnittyvistä teemoista. Nämä teemat vastasivat 
aineistossa parhaiten analyysikehikossa avun ehtona olevan perheen, omaisten ja läheisten olemassaolon tai informaalin avun puuttumista. Ilman omaisia oleminen, lapsettomuus ja naimattomuus vanhuusiässä on yhdistetty sosiaaliseen syrjäytymiseen ja sen riskiin useissa tutkimuksissa (esim. Deindl \& Brandt 2017) vaikkei yhteys olekaan väistämätön (esim. Dykstra \& Hagerstad 2007).

Tarkemman analyysin kohteeksi valittiin 1) informaaliin/palkattomaan hoivaan, 2) formaaliin/ammatilliseen hoivaan tai 3) yksinäisyyteen tai syrjäytymiseen liittyvät kehittämishankkeet. Tekstianalyysin kohteeksi otettiin näiden kehittämishankkeiden osalta kaikki www-sivuilta löydetty materiaali (hankehakemukset, hankeraportit ja wwwsivut). Nämä aineistolähteet on esitelty liitetaulukossa 2. Kielellisestä analyysistä jätettiin harkinnan jälkeen pois loppuraportti, jonka toinen tämän artikkelin kirjoittajista oli laatinut.

Aineiston puutteena oli, että vanhemmista hankkeista löytyi vähemmän materiaalia kuin uusista eikä aineiston kohdistumista teemoihin voinut aina niukan kuvauksen avulla päätellä. Luokittelun ulkopuolelle jäi siten paljon hankkeita. On myös huomioitava, että vain osa teemoista oli mukana teemayhdistelmissä. Esimerkiksi kotona asumisen ja kotihoidon teema, joka oli hyvin yleinen, ei ollut analyysissa mukana.Tämä johtui siitä, ettei teemaa ollut mahdollista sijoittaa joko informaalin tai formaalin hoivan alueelle.

Ylivoimaisesti eniten löytyi raha-automaattiyhdistyksen rahoittamia järjestöjen hankkeita, yhteensä 229 hanketta.
Muita hankkeita olivat erilaiset sosiaali- ja terveysministeriön ja kuntien rahoittamat ja yleensä sosiaalialan osaamiskeskuksen hallinnoimat hankkeet. Näitä muita hankkeita löytyi yhteensä yhdeksän.

\section{MiHIN VANHUSTYÖN \\ KEHITTÄMISHANKKEITA KOHDISTETTIIN?}

RAY:n kehittämishankkeiden ( $\mathrm{n}=229)$ yleisimmän teeman muodostivat perhe, omaiset ja omaishoito. Muita yleisiä teemoja olivat dementia ja muistiterveys, fyysisen toimintakyvyn edistäminen, kotona asumisen tuki, vertaistuki sekä neuvonta ja ohjaus (taulukko 2). Edellä mainitut teemat yhdistyivät usein samoissa hankkeissa esimerkiksi siten, että ikääntyneiden muistisairaiden omaishoitoa pyrittiin tukemaan nimenomaan vertaistuen avulla. Neuvonta ja ohjaus -teema yhdistyi hankkeissa myös yleisesti juuri omaishoitoon ja dementiaan sekä lisäksi teknologiaan. Yksinäisyys oli teemana seitsemässä RAY-hankkeessa, samoin syrjäytyminen. Ainoastaan muutama hanke sijoittui muuhun kuin kotona asumisen toimintaympäristöön.

Kun tarkastellaan 1) epäviralliseen ja palkattomaan apuun, 2) viralliseen ja ammatilliseen apuun ja 3) yksinäisyyteen ja syrjäytymiseen liittyviä hankkeita, RAY:n hankkeista huomattavasti suurin osa kohdistui epäviralliseen ja palkattomaan apuun. Myös hankerahoituksesta noin kolmasosa kohdistui näihin epävirallista apua kehittäviin hankkeisiin (kuvio 1). Monissa hankkeissa epävirallinen ja palkaton apu esiintyi teemoissa moninkertaisesti. 
Taulukko 2. RAY:n rahoittamien vanhustyön kehittämishankkeiden $(n=229)$ yleisimmät teemat.

\begin{tabular}{l|r} 
Teema & $\mathrm{n}=$ \\
\hline Perhe, omaiset, omaishoitajat, omaishoito & 55 \\
Fyysinen toimintakyky, kuntoutus, liikunta & 50 \\
Dementia, muistiterveys & 46 \\
Kotona asuminen, kotihoito, kotiutuminen & 35 \\
Vapaaehtoiset, vertaistuki & 30 \\
Neuvonta, ohjaus & 23 \\
Mielenterveys, masennus & 17 \\
Uudet toimintamallit & 17 \\
Kohtaamispaikat & 15 \\
Teknologia & 14
\end{tabular}

Esimerkiksi hankkeessa Omaishoidon $1 \ddot{a}-$ hettiläät se kohdistui (1) omaishoitajien (2) sosiaalisen verkoston vahvistamiseen (3) vapaaehtoistyön avulla.
Valtion rahoittamat hankkeet kohdistuivat RAY-hankkeita useammin viralliseen, palkallisena työnä annettavaan apuun ja erityisesti palvelurakenteeseen

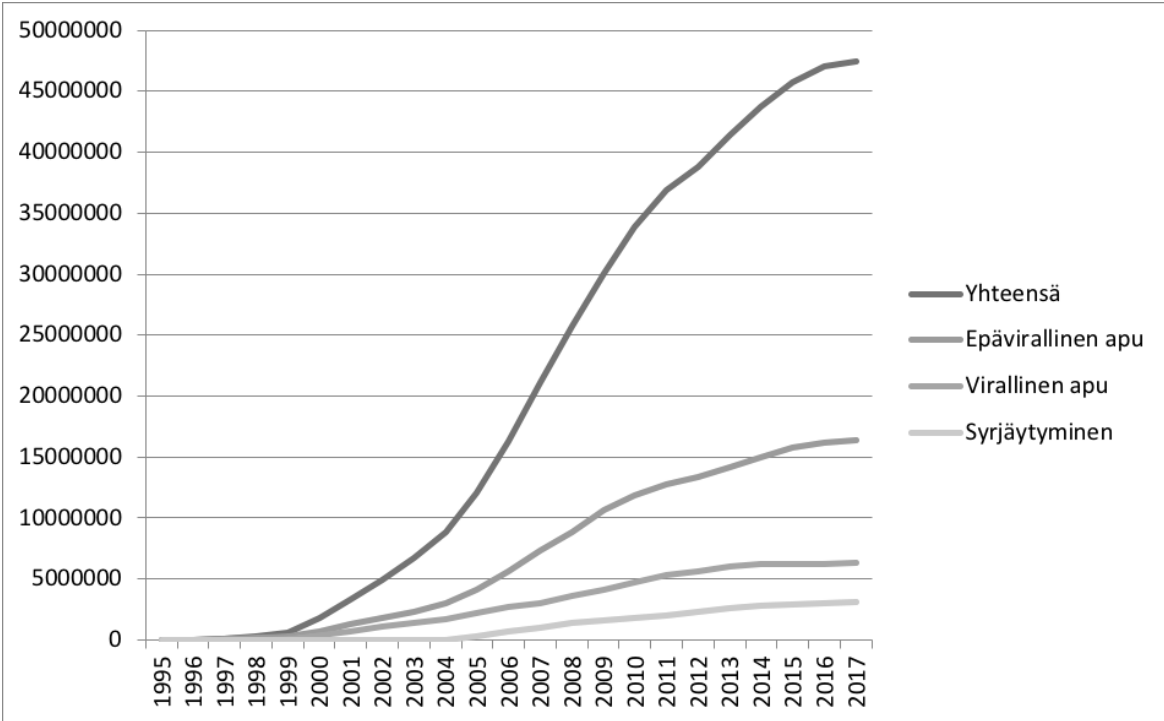

Kuvio 1. RAY:n hankerahoitus vuosittain (kumulatiivinen, $€$ ) epävirallisen avun, virallisen avun ja yksinäisyyden ja syrjäytymisen hankkeille. 
liittyviin kysymyksiin. Kuitenkin myös niissä viralliseen apuun yhdistyivät informaaliin apuun kohdistuvat teemat, kuten omaiset ja vapaaehtoiset. Informaali hoiva ulottui formaalin alueelle (myös Zechner 2010) siten, että kehittämishankkeissa sitä (informaalia) nimenomaan kutsuttiin sinne (formaaliin). Myös virallisen avun painottuminen kotiympäristöön toi epäviralliset toimijat mukaan hankkeisiin.

\section{KeHITTÄMISHANKKEIDEN PERUSTELUT}

Keskeisimpänä perusteluna vanhustyön kehittämiselle ja tehostamiselle toimivat yleensä väestön ikääntyminen ja sen mukanaan tuomat kustannuspaineet. Hankkeissa vedottiin strategioihin ja ohjelmiin, joilla näitä kustannuspaineita pyrittiin hillitsemään erityisesti kotiin suunnattavilla itsenäistä selviytymistä tukevilla palveluilla. Kehittämistoimintaa perusteltiin pohdinnan arvoisesti myös sillä, ettei aiempi mittavakaan ohjelma- ja kehittämistyö ollut saanut aikaan toivottuja muutoksia vanhustyössä. (Taulukko 3.)

Epävirallisen avun ja kotihoidon kehittämisen perusteluna erityisesti STM:n rahoittamissa hankkeissa oli kuntien taloudellinen tilanne. Kuntien resurssien niukkuus toimi perusteluna myös järjestöjen epäviralliseen apuun ja ennaltaehkäisyyn kohdistuville hankkeille, sillä viralliselta taholta toteutetun ammatillisen työn oletettiin kohdistuvan toisaalle. Nostalgia-hankkeen loppuraportin mukaan "niukkenevassa taloudellisessa tilanteessa ammattilaisten osuus kohdistuu korjaavaan työhön ja vapaaehtoisten tukemiseen."
Toisena vahvana perusteluna epävirallisen avun tukemiselle toimivat yhteiskunnassa tapahtuvat rakennemuutokset ja yksilölliset ikääntymiseen liittyvät muutosvaiheet. Ikääntyneiden muuttaessa keskustoihin vanhat verkostot katoavat. Lisäksi maahanmuuttajataustaisten vanhojen ihmisten määrä kasvaa. Oras-hankkeessa nähtiin, että hoivan tarvitsijan muuttaminen kotoa laitokseen kuormittaa niin omaista kuin hoivan tarvitsijaa, ja että hanketoiminnalla tätä muutosta oli mahdollista tukea. Hankkeessa ohjattiin ammattihenkilöstöä kohtaamaan muutosvaihetta läpikäyviä omaisia, läheisiä ja asukkaita.

Järjestöjen hankkeiden kohdistumista epävirallisiin ja palkattomiin toimijoihin perusteltiin sillä, että juuri nämä toimijat mahdollistavat sosiaalisen $\mathrm{ja}$ mielekkään elämän jatkumisen. Vapaaehtoisilla ja vertaistoimijoilla nähtiin arvoa sinänsä rinnalla kulkijoina kun ammatillinen toiminta painottui (fyysisten) perustarpeiden turvaamiseen.

Kiinnostavasti myös omaisiin kohdistuvia kehittämishankkeita perusteltiin syrjäytymisen ehkäisemisellä. Myös huonokuntoisen ikäihmisen omaiset ovat vaarassa syrjäytyä ilman tukea. Ulpu-projektissa kunnallisen tuen ulkopuolella olevat omaishoitajat olivat yksi tällainen ryhmä. Aineistosta oli myös luettavissa, että syrjäytymistä ehkäisevään ryhmätoimintaan osallistuneet eivät kuitenkaan aina tunnistaneet itseään syrjäytymisriskissä oleviksi. Näin oli Nostalgia-hankkeessa, jonka kehittämishankeraportissa ryhmään osallistunut vastasi, ettei ryhmällä ollut vaikutusta yksinäisyyden ja masennuksen tunteisiin, "koska ei koe olevansa yksinäinen tai masentunut (...)". 
RAY:n rahoittamien hankkeiden suuntautumiselle informaaliin ja palkattomaan hoivaan, kuten omaishoitoon ja vapaaehtoistoimintaan, on rahoitustekniset syynsä. Rahoitusta ei ole voinut hakea kunnan oman palvelutuotannon rahoittamiseen. Näin moninkertainen informaalin avun korostaminen viitannee kuitenkin myös vahvoihin kehittämistyön puhetapoihin, jotka ohjaavat hankehakemuksia tiettyihin teemoihin.

Virallisen, ammatillisen, avun kehittämiselle näytti olevan ylipäätään vaikeaa löytää perusteluja. Tämä herätti tutkijalukijan kysymään, oliko virallisen avun kehittäminen itse asiassa tavoitteena lainkaan. Luennan myötä aineistosta hahmottuikin tietty rakenne koskien virallisen avun alueelle ulottuvia hankkeita. Niissä itse virallista, ammatillista apua ja hoivaa sinänsä ei perusteltu millään. Sen sijaan kehittämistyössä perusteltiin sitä, miksi virallisen hoivan alueelle on syytä ottaa mukaan epävirallisia ja palkattomia toimijoita, kuten omaisia, vapaaehtoistyöntekijöitä ja vertaistoimijoita. Sama koski sekä valtiorahoitteisia että järjestöjen hankkeita.

Perustelut, joissa olisi tuotu esille kasvavan vanhusväestön tai perheettömien vanhusten julkisen hoivan tarpeita ja tavoiteltu julkisen avun saatavuuden ja kattavuuden lisäämistä, puuttuivat kokonaan. Sen sijaan kasvavaa vanhusväestöä ja sen hoivatarvetta käytettiin tehostamisen ja kustannusten leikkaamisen perusteluna. Kehittämishankkeissa informaalin hoivan ja vapaaehtoisavun ehdot (taulukko 1, esim. omaisen olemassaolo) otettiin usein itsestään selvänä taustaoletuksena, paitsi kun kyseessä katsottiin olevan syrjäy-

Taulukko 3. Kehittämishankkeiden perustelut.

\begin{tabular}{|l|l|}
\hline Mitä perustellaan & Miten perustellaan \\
\hline \multirow{2}{*}{$\begin{array}{l}\text { Kehittämistyö } \\
\text { yleensä }\end{array}$} & Kuntien taloudellinen tilanne \\
\cline { 2 - 2 } & Väestön ikääntyminen \\
\cline { 2 - 2 } & Aikaisempi kehittämistyö ei ole tuottanut tulosta \\
\hline $\begin{array}{l}\text { Informaaliin ja } \\
\text { palkattomaan } \\
\text { hoivaan } \\
\text { kohdistuva } \\
\text { kehittämistyö }\end{array}$ & Strategiset valinnat (kotona asumisen painottaminen) \\
\cline { 2 - 2 } & Yhteiskunnan rakennemuutos (muutot keskustaan, verkostojen puute) \\
\cline { 2 - 2 } & Mahdollistaa harrastamisen (vapaaehtoistoimija) \\
\cline { 2 - 2 } $\begin{array}{l}\text { Formaaliin ja } \\
\text { ammatilliseen } \\
\text { hoivaan } \\
\text { kohdistuva } \\
\text { kehittämistyö }\end{array}$ & Huonokuntoisten pariskuntien avun tarve \\
\cline { 2 - 2 } & Perheiden tuen tarve \\
\cline { 2 - 2 } $\begin{array}{l}\text { Yksinäisyyden ja } \\
\text { syrjäytymisen } \\
\text { torjunta }\end{array}$ & Omaisten uupumisen ehkäisy \\
\cline { 2 - 2 } & Kiire ja niukat resurssit (psykososiaalisen vanhustyön unohtuminen) \\
\cline { 2 - 2 } & Verkostojen puute \\
\hline
\end{tabular}


tyminen. Muissa kuin syrjäytymisen kysymyksissä sitä mahdollisuutta, ettei ehto toteutuisi, ei yleensä nostettu esille lainkaan. Esimerkiksi hankkeessa Kotona kokonainen elämä todetaan, että "Suomen paras kotihoito tehdään yhdessä aktiivisten ikäihmisten ja omaisten sekä yhteistyökumppaneiden kanssa.” Tämä oletus legitimoi kehittämistyön suuntaamista pois julkisista sosiaali- ja terveyspalveluista kohti muiden toimijoiden tuottamaa apua. Näiltä muilta myös odotetaan aktiivista toimijuutta hoivan tuottamisessa.

\section{KEHITTÄMISHANKKEIDEN SAAVUTUKSET}

Kehittämishankeraportit esittelivät monisanaisesti hankkeen aikana kehitettyjä verkostoja, koulutusta, työmenetelmiä (verkossa tapahtuva työ, kehittämispajat) ja uusia lähestymistapoja (ratkaisukeskeisyys, voimavaralähtöisyys) vanhustyöhön. Hankkeisiin oli usein kuulunut myös tiedonkeruuta kunnan palveluista ja väestöstä ja tiedon tuomista julki sitä tarvitseville. Kuitenkin hankkeiden konkreettiset vaikutukset esitettiin hankeraporteissa pääosin oletuksina. Monenlaiset samanaikaiset muutokset kunnissa ja muussa toimintaympäristössä sekä toisten hankkeiden, kuten Paras-hankkeen, vaikutukset olivat heijastuneet hanketyöhön. LänsiUudenmaan vanhustenpalvelujen kehittämisyksikkö -hankkeen loppuraportin sanoin näitä etenemiseen vaikuttaneista tekijöitä olivat: "Toimintayksikön muutokset osana kuntaorganisaatioiden uudelleenorganisointia, projektihenkilöstön vaihtuvuus, kuntien taloudellisen tilanteen heikkeneminen sekä hanketavoitteiden muuttuminen ja osittainen pienentyminen (...)"
Kehittämishankkeiden ylivoimaisesti yleisimpänä varsinaisena tuloksena esitettiin toimintamalli kehitettävänä olevasta asiasta. Osassa hankkeita malli oli kuvattu THL:n ylläpitämällä Innokyläsivustolla, jonka tavoitteena on hyvien käytäntöjen levittäminen ja jakaminen. Vain pienessä osassa hankkeita mallin osoitettiin jääneen elämään hankkeen jälkeen, ja suuressa osassa hankeraportteja jatko jäi epävarmaksi. Osassa hankkeita korostettiin nimenomaan, että erityisesti vapaaehtoistyöhön nojaavat toiminnat tarvitsisivat jatkuakseen ammatillisen työntekijän tukea, kuten esimerkiksi Nostalgia-hankkeessa. Myös jatkorahoituksen puuttuminen, joskus alkuperäisen hankesuunnitelman lupauksista huolimatta, vaikutti tavoitteiden toteutumiseen. Hankkeiden raportoituja tuloksia merkittävämpiä vaikutuksia vanhustyössä saattavatkin tuottaa juuri diskursiivisten ehtojen kautta rakentuvat merkitykset ja sitoumukset.

Useimmiten oli vaikea tulkita hankkeiden hyötyä omaisettoman hoivan tarvitsijan kannalta. Sen sijaan virallisen hoivan alueella, ikääntyneiden laitosasumisympäristössä, toteutettiin nimenomaisesti omaisyhteistyöhön kohdistuva Oras-hanke. Omaisyhteistyöllä tavoiteltiin virallisen hoidon laadun ja asukaslähtöisyyden parantumista, mutta epäselvää oli, koskiko tämä vain niitä asukkaita, joilla oli omainen. Omaisten puuttuminen joka tapauksessa kehotettiin huomioimaan hoitosuunnitelmassa ja asumisessa.

Myös omaisettomien hoivan tarvitsijoiden arkea hyödyttäviä hanketuotoksia oli aineistosta luettavissa. Vapaaehtoistoimintaa ja virallisen avun verkostoja yhdistävässä Nostalgia-hankkeessa ma- 
sentuneisuutta ja syrjäytymistä ehkäisevät, kaksi vuotta kokoontuneet ohjatut vertaisryhmät olivat hioutuneet yhteen ja parantaneet osallistujien elämänlaatua. Ryhmään saivat osallistua kotona asuvien vanhojen ihmisten lisäksi myös vanhainkodissa asuvat yksinäisyyttä kokevat ikäihmiset, joista monen "ystäväja sukulaisverkosto on olematon".

\section{YhteENVETO}

Tutkimuksen tulokset vahvistavat ja tekevät näkyväksi vanhuspolitiikan pyrkimystä siirtää hoivaan liittyviä tehtäviä informaalien ja palkattomien toimijoiden vastuulle. Vanhustyön kehittämishankkeissa hoivaa on pyritty siirtämään erityisesti perheiden ja vapaaehtoistoimijoiden tehtäväksi ja hankekieli on rakentunut näiden vahvojen puhetapojen ympärille. Tästä yhteiskunnallisen työnjaon siirtymästä ja sen sukupuoli- ja muista vaikutuksista ei ole käyty laajamuotoista yhteiskunnallista keskustelua. Kyse on hiljaisista siirroista (Julkunen 2006), jotka eivät välttämättä tule näkyviin yksittäisiä hankkeita tarkastelemalla. Suunta on kuitenkin selkeä, kun tarkastelussa on suuri joukko vanhustyön hankkeita.

Oletuksena oli luettavissa, että julkisilla toimijoilla ei ole resursseja muihin kuin tiettyihin rajattuihin tehtäviin, ja että muut tehtävät, kuten sosiaalisen elämän vahvistaminen, ovat myös tavallaan julkisen kiinnostuksen ulkopuolella. On syytä pohtia, missä, milloin ja kenen toimesta tällainen yhteiskunnallinen sopimus on tehty (vrt. Kuusinen-James 2009).
Tutkimuksen toinen keskeinen tulos on, että kehittämishankkeissa julkisen hoivan avulla selviytyviä vanhoja ihmisiä ei esiinny juuri lainkaan. Kun perhe ja läheiset otetaan itsestään selvyytenä, syrjäytyminen näyttää olevan ainoa tapa käsitellä niitä,joilla ei perhettä tai muuta epävirallisen avun verkostoa ole. Jos omaisettomat vanhat ihmiset haluavat lukea itsensä osana kehittämishanketta, ainoa tarjolla oleva toimijapaikka on syrjäytyneen paikka. Perheettömät vanhukset eivät kuitenkaan itsestään selvästi koe itseään syrjäytyneiksi (Ahosola \& Lumme-Sandt 2016). Tämä tuli esille myös edellä mainitussa Nostalgiahankkeen vertaisryhmän osallistujille tehdyssä kyselyssä.

Vähättelemättä hankkeiden hyötyä ikääntyneiden toimintakyvyn ja sosiaalisen elämän tukemisessa voidaankin kysyä, minkälaista ideologiaa, toimintatapoja ja hankekieltä kehittämishankkeiden kautta on tuotu vanhustyön toimintakentille. Mitä merkitystä esimerkiksi perheettömien laitoksessa asuvien vanhojen ihmisten hoivan kannalta on ollut sillä, että kehittämistyö painottuu näin vahvasti omaishoitoon ja kotona asuvien ikäihmisten ja perheiden tukemiseen?

On merkittävää, ettei hankerahaa ole juurikaan kanavoitu ilman omaisten tukea eläville vanhoille ihmisille. Vielä merkittävämpää on se, että he jäävät kaiken eteenpäin suuntaavan toiminnan ja puheen ulkopuolelle. Voidaan myös pohtia, olisiko vanhustenhuollon julkisuuskuva parempi, jos suurempi osa hankerahoituksesta olisi suunnattu julkisen hoivan kehittämiseen ammatilliseen hoivaan nojautuvin ratkaisuin. 
Vaikka useimpien hankkeiden tuloksista saatavia hyötyjä on vaikea varsinaisesti todentaa, niitä on helppo ymmärtää olevan runsaasti. Esimerkiksi Eloisa ikä -ohjelmasta tehdyssä tutkimuksessa hankkeiden todettiin hyödyntävän erityisesti vaikeassa elämäntilanteessa olleiden ikäihmisten psykososiaalista hyvinvointia (Pietilä \& Saarenheimo 2017). Ikääntyneiden sosiaalisen elämän elävöittäminen ja hanketoimijoiden ammatilliset ja ei-ammatilliset verkostot ovat esimerkkejä hankkeiden aikana saaduista hyödyistä. Verkostoja ja vertaistuen toimintamalleja on myös jäänyt elämään ja uudet toimintamallit uudistaneet työtä.

Kehittämistyön vahvistuminen ja hankeammattilaisten määrän ja osaamisen lisääntyminen näyttäytyy hankeraporttien kehittymisenä vuosien kuluessa. Samalla kuitenkin kehittämishankkeissa alkavat yhä vahvemmin toistua tietyt teemat. Epävirallinen apu mahtuu hallitsevien diskurssien sisälle paljon paremmin kuin virallisen avun kysymykset. Kun omaishoidon ja vapaaehtoistyön diskurssit hallitsevat kehittämispuhetta, ainoa tapa saada hankerahoitusta on nojautua niihin. Avun tarvitsijat saattavat olla toisaalla, ja käytännössä hanketta on joissain tapauksissa suunnattukin hiukan uudelleen.

Epävirallisen avun korostamista ja kasvua voidaan pitää jopa hyvinvointivaltion epäonnistumisen mittarina (esim. Heikkilä 2000, 178). Syrjäytymiskeskustelun ulottaminen läheis- ja sukulaissuhteiden puuttumisen alueelle viitannee siihen, että virallisen toiminnan vetäytyminen ymmärretään syrjäytymisriskinä, johon järjestöjen odotetaan vastaavan. Kehitys on huolestut- tavaa, etenkin kun tutkimukset samalla osoittavat, että ne jotka saavat vähiten informaalia hoivaa saavat vähiten myös formaalia hoivaa (Dahlberg \& McKee 2016).

On nostettu esille, etteivät kunnat tue riittävästi omaishoitoa ja leikkaavat juuri omaishoidon tukia määrärahojen huvetessa. Hankerahoituksen painottuminen näin vahvasti omaishoitoon tarjoaa toisenlaisen näkökulman kuntien suhtautumisesta omaishoitoon. Hankerahoituksen muodossa juuri omaishoito muodostaa keskeisen painopisteen, johon resursseja kohdistetaan (vrt. Kehusmaa ym. 2013). Omaishoidon hankkeiden painottaminen kehittämisrahoitusta jaettaessa selittyy pitkälti taloudellisilla tekijöillä. Toiveena on, että epävirallinen omaishoito siirtää kotitalouksille muutoin julkisen vallan vastuulle tulevia sosiaali- ja terveyspalveluiden kustannuksia. Vaikka tämän epävirallisen avun rahallista arvoa on vaikea arvioida, puhutaan kunnan kannalta hyvin merkittävästä säästöstä. (Kehusmaa ym. 2013.)

Omaisettomien hoivan tarvitsijoiden kannalta tarkasteltuna merkittävä tutkimustulos on, että vaikka vanhustyön kehittämiseen on kohdistettu valtava määrä hankerahaa, eivät hankkeet juuri lainkaan kohdistuneet muualla kuin kotona asuvien omaisettomien vanhojen ihmisten hoivaan tai vikistykseen. Tämä työ jää kokonaan hoiva-ammattilaisten tehtäväksi ja se tehdään kehittämis- ja strategiapuheen ulkopuolella. Julkisen avun vahvistaminen omaisettomille vanhuksille olisi hanketeemana suorastaan vallitsevien puhetapojen vastainen. Mikäli siihen haluttaisiin rahoitusta, siitä olisi puhuttava toisin. 
Syrjäytyminen näyttää kehittämishankemaailmassa ottaneen tämän tehtävän. Omaisettomille vanhuksille kyllä kehitetään toimintaa ja palveluita erilaisissa syrjäytymistä vastustavissa hankkeissa, mutta samalla heidät pakotetaan asettumaan tähän potentiaalisten syrjäytyneiden asemaan. On syytä pohtia, millaisin toimin omaisettomilla vanhoilla ihmisillä olisi parempi mahdollisuus toimia ja osallistua yhteiskuntaan itsenäisinä julkisten palveluiden avulla selviytyvinä toimijoina. Kotona asumisen hankkeiden suuren määrän vuoksi näitä hankkeita olisi jatkossa syytä tutkia tarkemmin juuri omaisettomien hoivan tarvitsijoiden näkökulmasta. Tämä olisi tärkeää siksi, että kotona asumisen painotus viittaa vahvasti informaalien verkostojen hyödyntämiseen. Samalla juuri kotiin tuotu riittävä formaali hoiva voi olla merkittävä tekijä omaisettomien vanhojen ihmisten toimijuuden kannalta.

\section{KirjallisuUs}

Aaltonen, Tarja \& Henriksson, Lea \& Karttunen, Aija \& Kivimäki, Riikka \& Palukka, Hannele \& Silvennoinen-Nuora, Leena \& Tiilikka, Tiina \& Valokivi, Heli (2009) Toimijat vanhusten hyvinvointipalveluja ohjaavissa kehittämisohjelmissa. Kunnallistieteellinen aikakauslehti 37 (3), 336-52.

Ahosola, Päivi \& Lumme-Sandt, Kirsi (2016) "Sen haluan ilmoittaa, että minä olen vielä pystyssä" Ilman omaisia elävien vanhojen ihmisten toimijuus ja vanhuspolitiikan kategorisoima vanhuus. Gerontologia 30 (4), 182-197.

Anttonen, Anneli (2009) Hoivan yhteiskunnallistuminen ja politisoituminen. Teoksessa Anneli Anttonen, Heli Valokivi \& Minna Zechner (toim.) Hoiva. Tutkimus, politiikka ja arki. Tampere:Vastapai- no, 54-98.

Anttonen, Anneli \& Häikiö, Liisa \& Raitakari, Suvi (2013) Matkalla ja muutokseen ja hyvinvointimarkkinoille. Janus 21 (4), 290-297.

Arpajaislaki. 23.11.2001/1046. Finlex.

Dahlberg, Lena \& McKee, Kevin (2016) Living on the Edge: Social Exclusion and the Receipt of Informal Care in Older People. Journal of Aging Research. https://doi.org/10.1155/2016/6373101

Deindl, Christian \& Brandt, Martina (2017) Support networks of childless older people: informal and formal support in Europe. Aging \& Society 37 (8), 1543-1567. https://doi.org/10.1017/ S0144686X16000416

Dykstra, Pearl A. \& Hagestad, Gunhild O. (2007) Roads Less Taken. Developing a Nuanced View of Older Adults Without Children. Journal of Family Issues 28 (10), 1275-1310. https://doi. org $/ 10.1177 / 0192513$ X07303822

Fairclough Norman (2003) Analyzing discourse. Textual analysis for social research. Oxon: Routledge. https://doi. org/10.4324/9780203697078

Filander, Karin (2000) Kehittämistyö murroksessa. Sitoutuminen, sopeutuminen ja vastarinta julkisella sektorilla 1990-luvulla. Acta Universitatis Tamperensis 777. Tampere:Tampereen yliopisto.

GeroMetro. http://www.socca.fi/kehittaminen/ikaihmisten_palvelut_gerometro, katsottu 11.2.2018.

Heikkilä, Matti (2000) Syrjäytymisen tutkimus 1990-luvulla. Teoksessa Matti Heikkilä \& Jouko Karjalainen (toim.) Köyhyys ja hyvinvointivaltion murros. Helsinki: Gaudeamus, 167-181.

Hoppania, Hanna-Kaisa \& Karsio, Olli \& Näre, Lena \& Olakivi, Antero \& Sointu, Liina \& Vaittinen, Tiina \& Zechner, Minna (2016) Hoivan arvoiset. Vaiva yhteiskunnan ytimessä. Helsinki: Gaudeamus.

Julkunen, Raija (2006) Kuka vastaa? Hyvinvointivaltion rajat ja julkinen vastuu. Helsinki: Stakes.

Kaljunen, Leena (2011) Johtamisopit kuntaorganisaatiossa. Diskursiivinen tutkimus sosiaali- ja terveystoimesta 1980-luvulta 2000-luvulle. Acta Universitatis Lappeenrantaensis 422. Lappeenranta: Lappeenrannan teknillinen yliopisto. 
Kehitetään ikäihmisten kotihoitoa ja vahvistetaan kaikenikäisten omaishoitoa. http:// stm.fi/hankkeet/koti-ja-omaishoito

Kehusmaa, Sari \& Autti-Rämö, Ilona \& Rissanen, Pekka (2013) Omaishoidon vaikutus ikääntyneiden hoidon menoihin. Yhteiskuntapolitiikka 78 (2), 138-151.

Kröger, Teppo (2009) Hoivapolitiikan rajanvetoja. Teoksessa Anneli Anttonen, Heli Valokivi \& Minna Zechner (toim.) Hoiva. Tutkimus, politiikka ja arki. Tampere:Vastapaino, 99-125.

Kuusinen-James, Kirsi (2009) Yhteinen vastuu - muuttuva työnjako? Uusi sosiaalinen sopimus ikääntyneiden hoivan järjestämisestä. Sosiaalityön erikoistumiskoulutukseen kuuluva lisensiaatin tutkimus. Valtiotieteellinen tiedekunta. Helsinki: Helsingin yliopisto.

Miller, Peter \& Rose, Nikolas (2010) Miten meitä hallitaan. Tampere:Vastapaino.

Paasivaara, Leena \& Suhonen, Marjo \& Virtanen, Petri (2013) Projektijohtaminen hyvinvointipalveluissa. Helsinki: Tietosanoma.

Pietilä, Minna \& Saarenheimo, Marja (2017) Ilmeikäs arki. Tutkimus ikääntyneistä ihmisistä järjestöjen kehittämistoiminnassa. Vanhustyön keskusliitto. https://www. eloisaika.fi/tutkimus/, luettu 12.2.2018.

Rinne, Päivi (2009) Matkalla muutokseen. Sosiaalialan projektitoiminnan perustelut, tavoitteet ja toimintatavat Sosiaaliturvalehden kirjoituksissa 1990-luvulla. Jyväskylä Studies in Education, Psychology and Social Research 356. Jyväskylä: Jyväskylän yliopisto.

Rostgaard, Tine \& Szebehely, Marta (2012) Changing policies, changing patterns of care:Danish and Swedish home care at the crossroads. European Journal of Ageing 9 (2), 101-109. https://doi.org/10.1007/ s10433-011-0209-1
Satka, Mirja \& Skehill, Caroline (2011) Michel Foucault and Dorothy Smith in case file research: Strange bed-fellows or complementary thinkers. Qualitative Social Work 11 (2), 191-205. https://doi. org/10.1177/1473325011400483

Sipilä, Jorma (2003) Hoivan organisointi: vaivaistalosta markkinatavaraksi. Janus 11 (1), 23-38.

Smith, Dorothy E (2005) Institutional ethnography. A sociology for people. The gender lens series. Lanham:AltaMira Press.

STM (2008) Sosiaalialan kehittämishanke 2003-2007. Loppuraportti. Salme Kallinen-Kräkin (toim.) Sosiaali- ja terveysministeriön selvityksiä 2008:6.

STM (2016) Sosiaali- ja terveydenhuollon kansallinen kehittämisohjelma (KASTE 2012-2015). Ulkoinen arviointi, loppuraportti. Sosiaali- ja terveysministeriön raportteja ja muistioita 2016:16. Helsinki: Sosiaali- ja terveysministeriö.

Sulkunen, Pekka (2006) Projektiyhteiskunta ja uusi yhteiskuntasopimus. Teoksessa Kati Rantala \& Pekka Sulkunen (toim.) Projektiyhteiskunnan kääntöpuolia. Helsinki: Gaudeamus, 17-38.

Suomen hallituksen strateginen ohjelma 2015. Ratkaisujen Suomi. Pääministeri Juha Sipilän hallituksen strateginen ohjelma 29.5.2015. Hallituksen julkaisusarja 10/2015. http://valtioneuvosto.fi/sipilanhallitus/hallitusohjelma luettu 27.1.2018

Van Aerschot, Lina (2014) Vanhusten hoiva ja eriarvoisuus. Sosiaalisen ja taloudellisen taustan yhteys avun saamiseen ja palvelujen käyttöön. Acta Universitatis Tamperensis 1971. Tampere:Tampere University Press.

Zechner, Minna (2010) Informaali hoiva sosiaalipoliittisessa kontekstissa. Acta Universitatis Tamperensis 1543. Tampere: Tampere University Press. 
Liitetaulukko 1. Teemat

\section{Teemat}

Dementia, muistiterveys

Fyysinen toimintakyky, kuntoutus, liikunta

Kohtaamispaikat

Kotona asuminen, kotihoito, kotiutuminen

Kuolema, saattohoito

Kulttuuri, taiteet, musiikki, tanssi

Maahanmuuttajavanhukset, monikulttuurisuus,

kielivähemmistöt

Mielenterveys, masennus

Monituottajuus

Neuvonta, ohjaus

Oma-apu, itsenäinen selviytyminen ${ }^{1}$

Osallistuminen, vaikuttaminen, itsemäärääminen

Perhe, omaiset, omaishoitajat, omaishoito ${ }^{1}$

Psykososiaalinen toimintakyky, toiminnallisuus, virkistys

Päivätoiminta, päiväkeskus ${ }^{2}$

Ravitsemus

Sairausryhmät, asiakasryhmät

Sosiaalinen verkosto ${ }^{1}$

Sukupolvet

Suru, kriisit, perheväkivalta

Syrjäytyminen, huono-osaisuus ${ }^{3}$

Teknologia, tietotekniikka

Terveyden edistäminen, ennaltaehkäisy

Turvallisuus

Uudet rakenteet ${ }^{2}$

Uudet toimintamallit, laatu ${ }^{2}$

Vanhustyöntekijät ${ }^{2}$

Vapaaehtoiset, vertaistuki ${ }^{1}$

Yhteisöllisyys

Yksinäisyys $^{3}$

Ympärivuorokautinen hoito, palvelutalot ${ }^{2}$

Yöhoito, -partio²

${ }^{1}$ informaali, palkaton apu

${ }^{2}$ formaali, ammatillinen apu

${ }^{3}$ yksinäisyys, syrjäytyminen 
Liitetaulukko 2. Aineistolähteet

\begin{tabular}{|c|c|c|c|c|}
\hline $\begin{array}{l}\text { Aloitus- } \\
\text { vuosi }\end{array}$ & Hanke & Toteuttaja & Rahoitus & Materiaalia \\
\hline 2006 & $\begin{array}{l}\text { Vapaaehtois- ja } \\
\text { vertaistoiminnan } \\
\text { kehittämiseen } \\
\text { viestintätekniikkaa } \\
\text { hyödyntäen } \\
\text { (Puhumalla paras) } \\
\end{array}$ & $\begin{array}{l}\text { Eläkeliitto } \\
\text { ry }\end{array}$ & RAY & $\begin{array}{l}\text { http://www.eläkeliitto.fi/toiminta/apunen- } \\
\text { auttava+vapaaehtoistoiminta/puhumalla+paras, } \\
\text { katsottu 8.5.2017. }\end{array}$ \\
\hline 2006 & $\begin{array}{l}\text { Disko - dementoituvan } \\
\text { itsenäinen } \\
\text { selviytyminen kotona - } \\
\text { hankekonsortio. Mara } \\
\text { - teknologia } \\
\text { dementoituvan ja } \\
\text { omaishoitajan tukena } \\
\text {-hanke. }\end{array}$ & $\begin{array}{l}\text { Palmenia, } \\
\text { Verso }\end{array}$ & $\begin{array}{l}\text { EAKR, } \\
\text { Kunnat, } \\
\text { Sosiaalitait } \\
\text { o, Verso }\end{array}$ & $\begin{array}{l}\text { Loppuraportti 1.9.2006-30.6.2008. Tulostettu } \\
\text { 31.7.2011 }\end{array}$ \\
\hline 2006 & $\begin{array}{l}\text { KUUMA-kuntien ja } \\
\text { Hyvinkään } \\
\text { vanhuspalveluiden } \\
\text { kehittämishanke } \\
\text { (Tulke) }\end{array}$ & $\begin{array}{l}\text { Tuusula \& } \\
\text { Keski- } \\
\text { Uuden- } \\
\text { maan } \\
\text { kunnat }\end{array}$ & $\begin{array}{l}\text { STM, } \\
\text { kunnat }\end{array}$ & Loppuraportti, tulostettu 31.7.2011 \\
\hline 2007 & $\begin{array}{l}\text { Kunnallisen tuen } \\
\text { ulkopuolella olevien } \\
\text { omaishoitajien } \\
\text { tukemiseen (Ulpu) } \\
\end{array}$ & \begin{tabular}{|l} 
Parhaat \\
vuodet ry
\end{tabular} & RAY & Loppuraportti 12.02.2010, tulostettu 31.7.2011 \\
\hline 2007 & $\begin{array}{l}\text { Länsi-Uudenmaan } \\
\text { vanhuspalvelujen } \\
\text { kehittämisyksikkö- } \\
\text { hanke }\end{array}$ & $\begin{array}{l}\text { Sosiaalitait } \\
\text { o, kunnat }\end{array}$ & $\begin{array}{l}\text { STM, } \\
\text { kunnat }\end{array}$ & $\begin{array}{l}\text { http://sosiaalitaito.fi/wp- } \\
\text { content/uploads/2013/02/Luvanke_loppuraportt } \\
\text { i2009Final.pdf, katsottu 12.2.2018 }\end{array}$ \\
\hline 2007 & $\begin{array}{l}\text { Vanhusten } \\
\text { masentuneisuuden } \\
\text { ehkäisyn tukemiseen } \\
\text { (Nostalgia) } \\
\end{array}$ & $\begin{array}{l}\text { Lähimmäis- } \\
\text { apu ry } \\
\text { (Lähde ry) }\end{array}$ & RAY & $\begin{array}{l}\text { http://www.talkoorengas.fi/muu_toiminta/nosta } \\
\text { lgia/index.html / katsottu 12.2.2018 } \\
\text { Loppuraportti, tulostettu 31.7.2011 }\end{array}$ \\
\hline 2009 & $\begin{array}{l}\text { Omaiset rakentamassa } \\
\text { asukaslähtöisyyttä } \\
\text { (ORAS) }\end{array}$ & $\begin{array}{l}\text { Omaisena } \\
\text { edelleen ry }\end{array}$ & RAY & $\begin{array}{l}\text { https://omaisenaedelleen.fi/projektit/omaiset- } \\
\text { rakentamassa-asukaslahtoisyytta-oras-projekti- } \\
\text { 2009-2011, katsottu 8.5.2017. Omaisyhteistyö } \\
\text { vanhuspalveluissa. } \\
\text { www.innokylä.fi/web/malli188673, katsottu } \\
\text { 8.5.2017. }\end{array}$ \\
\hline 2009 & $\begin{array}{l}\text { Omaishoitoperheiden } \\
\text { tukemiseen } \\
\text { voimavara-arvioin } \\
\text { avulla (Elinvoimaa ja } \\
\text { elämänhallintaa } \\
\text { omaishoitoperheille) } \\
\end{array}$ & $\begin{array}{l}\text { Kalliolan } \\
\text { seniori- } \\
\text { palvelu- } \\
\text { säätiö } \\
\end{array}$ & RAY & $\begin{array}{l}\text { http://www.seniorisandels.fi/sitenews/view/- } \\
\text { /nid/44/ngid/1, katsottu 12.2.2018 }\end{array}$ \\
\hline 2009 & $\begin{array}{l}\text { Palvelutalojen } \\
\text { päihdepelisääntöjen } \\
\text { kehittämiseen }\end{array}$ & $\begin{array}{l}\text { Kuntokallio } \\
\text {-säätiö }\end{array}$ & RAY & $\begin{array}{l}\text { http://www.ikainstituutti.fi/ikainstituutti/aikaise } \\
\text { mmat-hankkeet/paihdepelisaannot- } \\
\text { palvelutaloihin, katsottu 28.5.2017. }\end{array}$ \\
\hline
\end{tabular}




\begin{tabular}{|c|c|c|c|c|}
\hline $\begin{array}{r}\text { Aloitus- } \\
\text { vuosi }\end{array}$ & Hanke & Toteuttaja & Rahoitus & Materiaalia \\
\hline 2011 & $\begin{array}{l}\text { Vertaistuen } \\
\text { kehittämiseen } \\
\text { muistisairaille (Kamu) }\end{array}$ & $\begin{array}{l}\text { Vantaan } \\
\text { muisti- } \\
\text { yhdistys }\end{array}$ & RAY & https://www.innokyla.fi/web/hanke44150 \\
\hline 2012 & $\begin{array}{l}\text { Vapaaehtoistoimin- } \\
\text { taan ja promotiiviseen } \\
\text { mielenterveystyöhön } \\
\text { (TunneMieli) } \\
\end{array}$ & $\begin{array}{l}\text { Eläkeliitto } \\
\text { ry }\end{array}$ & RAY & $\begin{array}{l}\text { http://www.tunnemieli.fi/etusivu/ katsottu } \\
\text { 8.5.2017 }\end{array}$ \\
\hline 2012 & \begin{tabular}{|l|} 
Omaishoitajien \\
sosiaalisen \\
tukiverkoston \\
vahvistamiseen \\
vapaaehtoistoimin- \\
nalla (Omaishoidon \\
lähettiläät) \\
\end{tabular} & $\begin{array}{l}\text { Salon } \\
\text { omais- } \\
\text { hoitajat }\end{array}$ & RAY & $\begin{array}{l}\text { https://www.salonomaishoitajat.fi/yhdistys/paat } \\
\text { tyneet-projektit/ }\end{array}$ \\
\hline 2012 & $\begin{array}{l}\text { Omaishoitoperheiden } \\
\text { tukemiseen sekä } \\
\text { intervallihoito- } \\
\text { paikkojen ja } \\
\text { omaishoitoperheiden } \\
\text { välisen yhteistyön } \\
\text { kehittämiseen (ELO - } \\
\text { Elämä lähellä omaista) }\end{array}$ & $\begin{array}{l}\text { Hiiden } \\
\text { seudun } \\
\text { läheiset ja } \\
\text { omais- } \\
\text { hoitajat ry }\end{array}$ & RAY & $\begin{array}{l}\text { https://www.hiidenseudunomaishoitajat.fi/elo- } \\
\text { projektin-paatostilaisuus-11.2.2016, katsottu } \\
\text { 12.2.2018 }\end{array}$ \\
\hline 2013 & $\begin{array}{l}\text { VALTTI - } \\
\text { Gerontologisen } \\
\text { valmennuksen } \\
\text { toimintamallin } \\
\text { kehittäminen }\end{array}$ & $\begin{array}{l}\text { Sosiaalitait } \\
\text { o, Palmenia }\end{array}$ & & $\begin{array}{l}\text { http://sosiaalitaito.fi/wp- } \\
\text { content/uploads/2013/02/LOPPURAPORTTI- } \\
\text { VALTTI.pdf }\end{array}$ \\
\hline 2013 & $\begin{array}{l}\text { Kotona kokonainen } \\
\text { elämä }\end{array}$ & $\begin{array}{l}\text { Sosiaalitait } \\
\text { o, kunnat }\end{array}$ & STM & $\begin{array}{l}\text { https://kotonakokonainenelama.wordpress.com, } \\
\text { katsottu 12.2.2018 } \\
\text { https://www.innokyla.fi/documents/306104/0/L } \\
\text { oppuraportti_valmis.pdf/bc564b63-b5a2-4502- } \\
\text { b985-4e7f3d66dbc5, katsottu 12.2.2018 }\end{array}$ \\
\hline 2013 & \begin{tabular}{|l} 
Muistisairaiden \\
inmisten \\
varhaiskuntoutukseen \\
osallistavana \\
verkostomallina \\
(Muistiluuri) \\
\end{tabular} & $\begin{array}{l}\text { Miina } \\
\text { Sillanpään } \\
\text { säätiö }\end{array}$ & RAY & $\begin{array}{l}\text { https://www.miinasillanpaa.fi/hankkeet/kuntout } \\
\text { us/muistiluuri, katsottu 8.5.2017. }\end{array}$ \\
\hline 2016 & $\begin{array}{l}\text { Seremonia - Vantaan } \\
\text { monikansallisen } \\
\text { senioritoiminnan } \\
\text { kehittäminen } \\
\end{array}$ & $\begin{array}{l}\text { Vanhusten } \\
\text { kotiapu- } \\
\text { säätiö }\end{array}$ & RAY & http://seremonia.info/ katsottu 8.5.2017. \\
\hline 2017 & Täydentäen toimivaa & STM (I\&O) & STM & $\begin{array}{l}\text { http//stm.fi/koti-ja-omaishoito/rahoitettavat- } \\
\text { hankkeet/taydentaen-toimivaa, katsottu } \\
\text { 8.5.2017 }\end{array}$ \\
\hline
\end{tabular}

